\title{
MORPHOTYPES OF THE COCCOLITHOPHORE GEPHYROCAPSA AS A PROXY FOR SEA SURFACE TEMPERATURE
}

\author{
TARINE SILVEIRA SILVEIRA \\ Programa de Pós-Graduação em Oceanografia Física, Química e Geológica, Instituto de Oceanografia, \\ Universidade Federal do Rio Grande, Av. Itália, km 8, Cx.P. 474, 96201-900, Rio Grande, RS, Brazil. \\ tarine_silveira@hotmail.com
}

\author{
ADRIANA LEONHARDT \\ Laboratório de Paleoceanografia e Palinologia, Instituto de Oceanografia, Universidade Federal do Rio Grande, \\ Av. Itália, km 8, Cx.P. 474, 96201-900, Rio Grande, RS, Brazil.adriana.leonhardt@yahoo.com.br
}

\begin{abstract}
Previous works have established that six morphotypes of the genus Gephyrocapsa are recognized and related to the sea surface temperature. However, applying Gephyrocapsa morphotypes to reconstruct this parameter is challenging because morphotype descriptions and photographs are done in an Electron Scanning Microscope (SEM), while the majority of quantitative analysis research of fossil assemblages is done with an Optical Microscope (OM). Therefore, we aim to evaluate coccolith image correspondence in these two kind of microscopes. Four sediment core samples were used from the offshore section of the Pelotas Basin. For each sample and each analysis type, 60 coccoliths were measured, photographed, and classified by morphotype in the SEM and the OM. The morphotype proportions found in the SEM and the OM were correlated using a sum of squares statistical analysis. Weak correlations were found. It does not seem possible to securely identify Gephyrocapsa morphotypes in the OM, as the image differs considerably from that found in the SEM. Paleotemperatures were calculated from morphotype proportions in the SEM and the OM and discrepancies were very large, demonstrating that this proxy is not viable when studies are completed in the OM.
\end{abstract}

Key words: Gephyrocapsa, SST, optical microscope, electron microscope.

RESUMO - Trabalhos anteriores estabeleceram que seis morfotipos para o gênero Gephyrocapsa são reconhecidos, relacionados principalmente com a temperatura das águas superficiais. No entanto, a aplicabilidade dos morfotipos de Gephyrocapsa para a reconstrução deste parâmetro em trabalhos paleoceanográficos está comprometida porque as descrições e fotografias destes são feitas ao microscópio eletrônico de varredura (MEV), enquanto boa parte da pesquisa envolvendo a análise quantitativa da associação fóssil é feita ao microscópio óptico (MO). Assim, estabelecer uma correspondência entre as imagens dos cocólitos geradas pelas diferentes microscopias é o objetivo deste trabalho. Foram utilizadas amostras de topo de quatro testemunhos da porção offshore da Bacia de Pelotas. Em cada amostra e para cada tipo de análise, 60 cocólitos foram medidos, fotografados e classificados em morfotipos ao MEV e ao MO. As proporções de morfotipos encontradas ao MEV e ao MO foram correlacionadas a partir da estatística soma de quadrados. As correlações encontradas foram consideradas baixas. Não parece possível reconhecer com segurança os morfotipos de Gephyrocapsa ao MO, em função da diferença de imagem obtida nos dois tipos de microscopia. Ao analisar as paleotemperaturas calculadas a partir das proporções de morfotipos encontradas ao MEV e ao MO, discrepâncias muito grandes foram encontradas nos resultados, demonstrando a inviabilidade de utilizar este proxy em trabalhos realizados ao MO.

Palavras-chave: Gephyrocapsa, TSM, microscópio óptico, microscópio eletrônico.

\section{INTRODUCTION}

Many paleooceanographic studies aim to reconstruct past interactions between the ocean and the atmosphere to elucidate past global climate patterns. Many of these studies are performed with the aid of micropaleontology and, in this context, coccolithophores stand out. These algal protists produce small calcium carbonate plates called coccoliths that cover the cell and are preserved in marine sediments.

Coccolith morphology is the criteria most used to differentiate species of coccolithophores. In the case of paleoenvironmental studies based on their fossil assemblage, it is the only criteria. However, the same coccolithophorid species can present various phenotypes for different environmental gradientes. It is important to identify these different morphotypes because they serve as indicators of specific environmental conditions. Some examples, such as Gephyrocapsa spp., Emiliania huxleyi, Calcidiscus leptoporus and Coccolithus pelagicus, are well known (Bollmann, 1997; Renaud, et al. 2002; Hagino, et al. 2005; Bollmann \& Herrle, 2007). Here we present a study on the Gephyrocapsa spp. morphotypes. 
All coccoliths from the family Noelaerhabdaceae have a structure essentially similar one to the other: (i) distal shield (directed toward outer surface of the coccolithophore/ cell); (ii) proximal shield (directed toward the center of the coccolithophore/cell); (iii) central area (inner part of the coccolith, enclosed by the rim); (iv) rim (outer part of coccolith) (Young et al., 1997; Young et al., 2004) (Figure 1).

Coccoliths of the genus Gephyrocapsa are circular or subcircular, and have a bar situated on the distal shield. The bar is made of two plates that meet in the center region (PerchNielsen, 1985; Bollmann, 1997) (Figure 2).

Gephyrocapsa are present in all oceans in the world and are often expressive in both live populations of coccolithophores and fossil assemblages (Roth, 1994). Gephyrocapsa was globally dominant during a few Pleistocene intervals and was likely an important part of the global carbon cycle due to its great abundance (because, as all coccolithophore species, it precipitates and calcifies calcite crystals to form coccospheres); an analogous species that lives now is Emiliania huxleyi. The Gephyrocapsa is relatively abundant in Quaternary sediments, and various studies have already been perfomed on morphological changes in coccoliths with environmental gradients (Bollmann, 1997).

\section{Previous works}

Some studies about the morphological changes in Gephyrocapsa coccoliths over geologic time have been performed. Rio (1982) divided the genus into morphotypes that occur at different times in Pliocene and Pleistocene, based primarily on the size of coccoliths. Matsuoka \& Okada (1990) conducted a similar study, classifying the coccoliths according to their size and the inclination of the central bar. With this approach, it was possible to divide and identify different time intervals within the Quaternary through the occurence of morphotypes of Gephyrocapsa. However, these studies have a biostratigraphic approach, with little applicability in paleoceanographic research, since they do not attempt to relate the morphotypes with environmental parameters of surface water.

Bollmann (1997) analyzed the distribution of global Holocene sediments and found a significant correlation
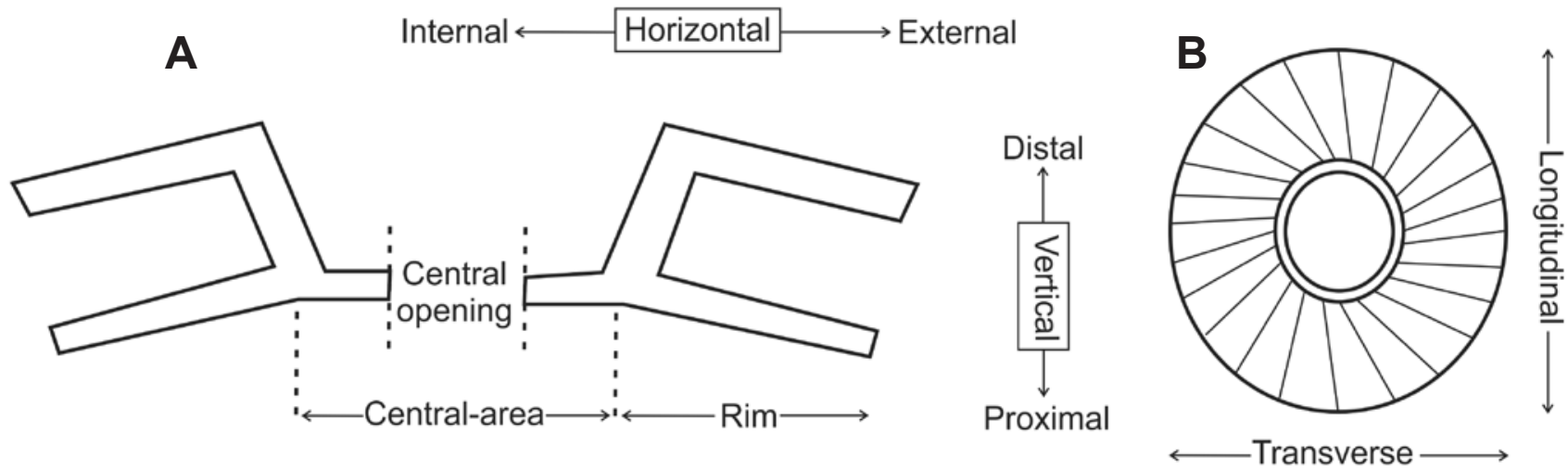

Figure 1. Representation of a coccolith. A, transversal view; B, frontal view (Young et al.,1997).

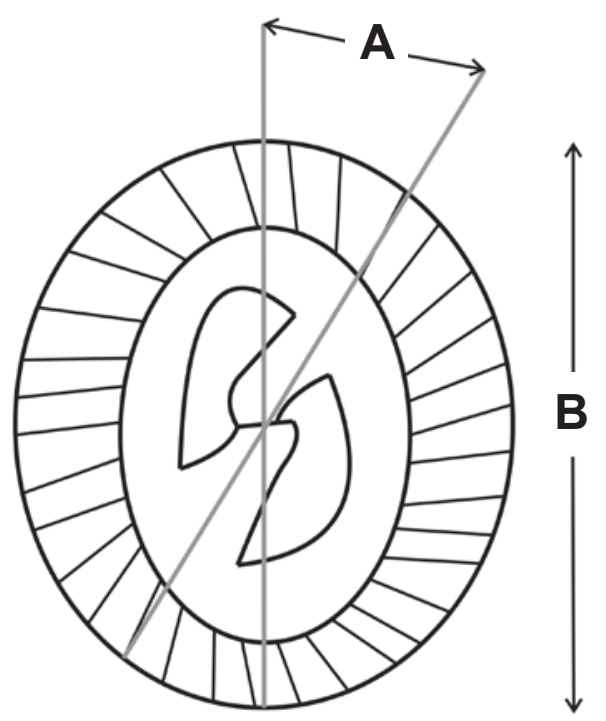

Figure 2. Representation of a Gephyrocapsa coccolith and of coccolith measurement with SEM. A, angle of inclination of central bar; B, greatest length of coccolith (Bollmann, 1997). 
Table 1. Morphotype characteristics Gephyrocapsa as described by Bollmann (1997).

\begin{tabular}{lcccc}
\hline \multicolumn{1}{c}{ Morphotype } & Coccolith length $(\mu \mathrm{m})$ & Central bar angle & Temperature & Observations \\
\hline Gephyrocapsa equatorial & $3.1-3.9$ & $>56^{\circ}$ & $25-29.5^{\circ} \mathrm{C}$ & Occurs in regions near the equator. \\
Gephyrocapsa oligotrophic & $>3.1$ & $27-56^{\circ}$ & $22-25^{\circ} \mathrm{C}$ & Only found in subtropical oligotrophic regions. \\
Gephyrocapsa transitional & $2.4-3.1$ & $27-56^{\circ}$ & $27-56^{\circ}$ & - \\
Gephyrocapsa cold & $>2.4$ & $<27^{\circ}$ & $<21^{\circ} \mathrm{C}$ & Occurs in moderately productive regions. \\
Gephyrocapsa large & $>3.9$ & $>56^{\circ}$ & - & $\begin{array}{l}\text { Dominant in temperate and highly productive areas } \\
\text { of coastal upwelling. }\end{array}$ \\
Gephyrocapsa minute & $<2.4$ & $20-50^{\circ}$ & - & $\begin{array}{l}\text { Does not have obvious environmental preferences. } \\
\text { Common in tropical or subtropical neritic zones. }\end{array}$ \\
\hline
\end{tabular}

between morphological parameters in Gephyrocapsa coccoliths (diameter and inclination of the central bar, Figure 2) and environmental gradients. The analysis revealed six distinct morphological associations, characterizing equatorial to temperate environments and high to low productivity (Table 1). At least five of them are highly correlated with specific environmental conditions.

Evidence from Holocene samples in the Atlantic, Indian, and Pacific oceans suggest that the sea surface temperature (SST) can be calculated using the relative abundance of Gephyrocapsa morphotypes in superficial sediment samples, with a standard deviation comparable to estimates from temperatures derived from a transfer function based on planktonic formanifera (Bollmann et al., 2002). This new proxy makes the reconstruction of paleotemperatures possible with very small quantities of sediments, facilitating studies with higher temporal resolution.

However, the aplicability of Gephyrocapsa morphotypes is compromised by the fact that descriptions and photographs of morphotypes are done with a scanning electron microscope (SEM). Quantitative analysis of the fossil assemblage is generally done with a petrographic optical microscope (OM), generating images very distinct from those observed with a SEM. Therefore, identifying a correspondence between the different images generated by the two microscopes is necessary to spread the use of morphotypes in reconstructing SST. This study aims to evaluate the viability of identifying Gephyrocapsa morphotypes in the OM.

\section{MATERIAL AND METHODS}

\section{Studied samples}

Studied samples were obtained from four sediment cores from an offshore area of the Pelotas Basin (Table 2) (Figure 3). This region is located between the Subtropical Convergence Zone (STCZ) and the Intertropical Convergence Zone (ITCZ) and is influenced by the Brazilian Current. Sediment cores were collected using a piston corer. Only samples from the top of the sediment cores were analyzed. The sediment cores, including top samples, are composed of fine sediments. Sample preparation was done according to Koch \& Young (2007).
Table 2. Data on the four sediment cores used in the study.

\begin{tabular}{ccc}
\hline Samples & Coordinates & Water depth (m) \\
\hline REG 276 & $-30.299496^{\circ} \mathrm{S} ;-47.099538^{\circ} \mathrm{W}$ & 2148 \\
REG 304 & $-30.449467^{\circ} \mathrm{S} ;-47.249528^{\circ} \mathrm{W}$ & 2212 \\
REG 301 & $-30.44943^{\circ} \mathrm{S} ;-47.099523^{\circ} \mathrm{W}$ & 2098 \\
SAT 073 & $-29.405221^{\circ} \mathrm{S} ;-47.307677^{\circ} \mathrm{W}$ & 1613 \\
\hline
\end{tabular}

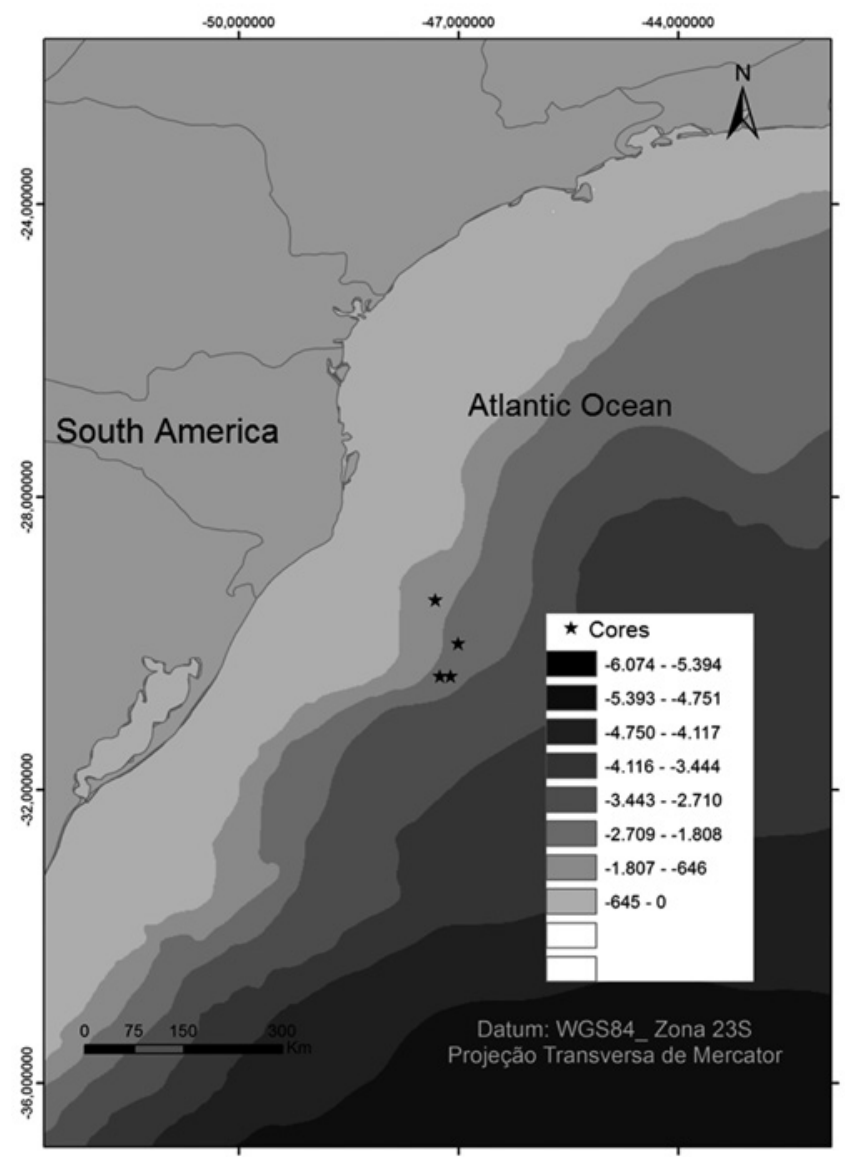

Figure 3. Location of the four sediment cores used. 


\section{Microscopy analysis}

For each sample and each analysis type, 60 coccoliths were photographed and measured with a SEM and an OM. A 1000x magnification was used in the OM (Meiji Techno, model MT9430L) and a magnification between 9000x and 18000x was used in the SEM (JEOL, model JSM-6610LV).

Morphotype classification was based on the greatest length of the coccolith and the angle between the greatest length and the central bar in the clockwise direction (Bollman, 1997), as can be seen in detail in the Table 1. With the SEM, measurements were simple, as can be seen in Figure 2. With the OM, two methods were employed to measure the angle.

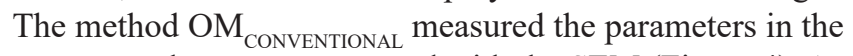
same way they were measured with the SEM (Figure 4). As the continuity of the coccolith rim could not be observed in the OM, another measurement strategy was used, called $\mathrm{OM}_{\text {ALTERNATIVE }}$. In this method, an axis was established linking the portions of the rim in which the conexion with the central bar can be seen (Figure 5). The angle was measured between this axis and the central bar, in the clockwise direction. With this new measurement method, we hope to include the observer perception of the bar's inclination when examining coccoliths in the OM, as in studies involving quantitative analysis of the assemblage, the coccoliths are not measured one by one.

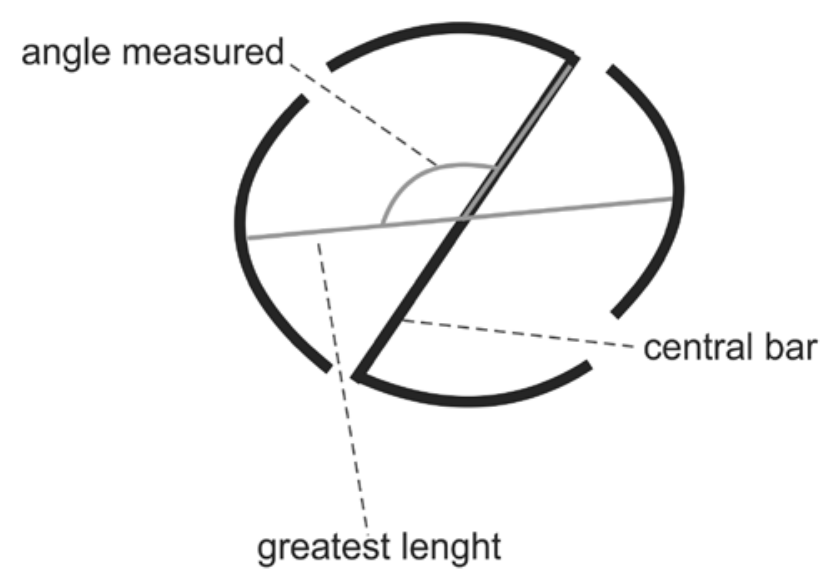

Figure 4. Representation of coccolith measurement using OM CONVENTIONAL $_{\text {method. }}$

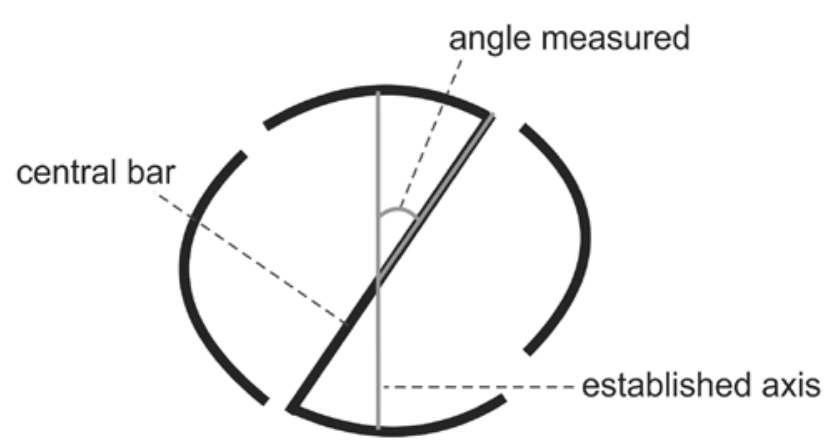

Figure 5. Measurement of the angle of incliniation of the coccolith's central bar using the OM ALteRnATIVE $_{\text {method. }}$

\section{Statistical analysis}

The analyzed samples in the SEM and the OM were correlated based on the proportion of morphotypes found in each one, in order to evaluate the success of morphotype recognition in the OM. The sum of squares method was used and the analyses were done using the software Multiv (Pillar, 2006).

\section{Mean sea surface temperature}

Bollmann et al. (2002) proposed the following equation to calculate mean SST, using proportions of three morphotypes of Gephyrocapsa:

$$
\begin{gathered}
\mathrm{SST}=19.4336+(0.1161 \times \% \mathrm{GE}) \\
+(-0.0560 \times \% \mathrm{GC})+(0.0806 \times \% \mathrm{GO})
\end{gathered}
$$

where: SST $=$ Sea Surface Temperature; $\mathrm{GE}=$ Gephyrocapsa "equatorial"; $\mathrm{GC}=$ Gephyrocapsa "cold"; $\mathrm{GO}=$ Gephyrocapsa "oligotrophic".

The SST was calculated for the top sample of the four sediment cores from the data obtained in SEM and OM.

\section{RESULTS AND DISCUSSION}

\section{Morphotype analysis}

All of the six morphotypes described by Bollmann (1997) were found in the analyzed samples.

More coccoliths of the equatorial Gephyrocapsa morphotype (Figure 6) were identified with $\mathrm{OM}_{\text {CONVENTIONAL }}$ than with the SEM in all samples. In the specific case of sample SAT073, no coccoliths were identified from the equatorial Gephyrocapsa morphotype in the SEM. This morphotype was not found in any of the samples using $\mathrm{OM}_{\text {ALTERNATIVE }}$ (Figure 7).

The oligotrophic Gephyrocapsa morphotype (Figure 8) showed different abundance percentages in the OM and the SEM when comparing the samples. With $\mathrm{OM}_{\text {CONVENTIONAL }}$, the proportions of coccoliths of the oligotrophic morphotype are always underestimated when compared to those found in the

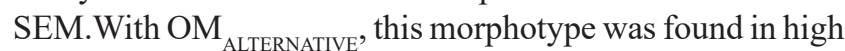
percentages in samples REG276, REG301, and REG304, but was underestimated with the SEM in sample SAT073 (Figure 9).

The transitional Gephyrocapsa morphotype (Figure 10) was not found in sample SAT073. It was also not found with the SEM in sample REG304 and with $\mathrm{OM}_{\text {CONVENTIONAL }}$ in sample REG301. The sample REG304 stood out due to the high percentages of the morphotype found with OM $\mathrm{MLTERNATIVE}_{\text {. }}$ when compared to other forms of measurement (Figure 11).

The cold Gephyrocapsa morphotype (Figure 12) was found in higher percentages in the SEM rather than $\mathrm{OM}_{\text {CONVENTIONAL }}$ in all samples. Furthermore, the morphotype is better represented by $\mathrm{OM}_{\text {ALTERNATIVE }}$ than the SEM, and this preference is stronger for sample SAT 073 (Figure 13).

The larger Gephyrocapsa morphotype (Figure 14) showed relatively similar percentages for analyses completed with the SEM and with OM $\mathrm{CONVENTIONAL}_{\text {, }}$ with the exception of sample 


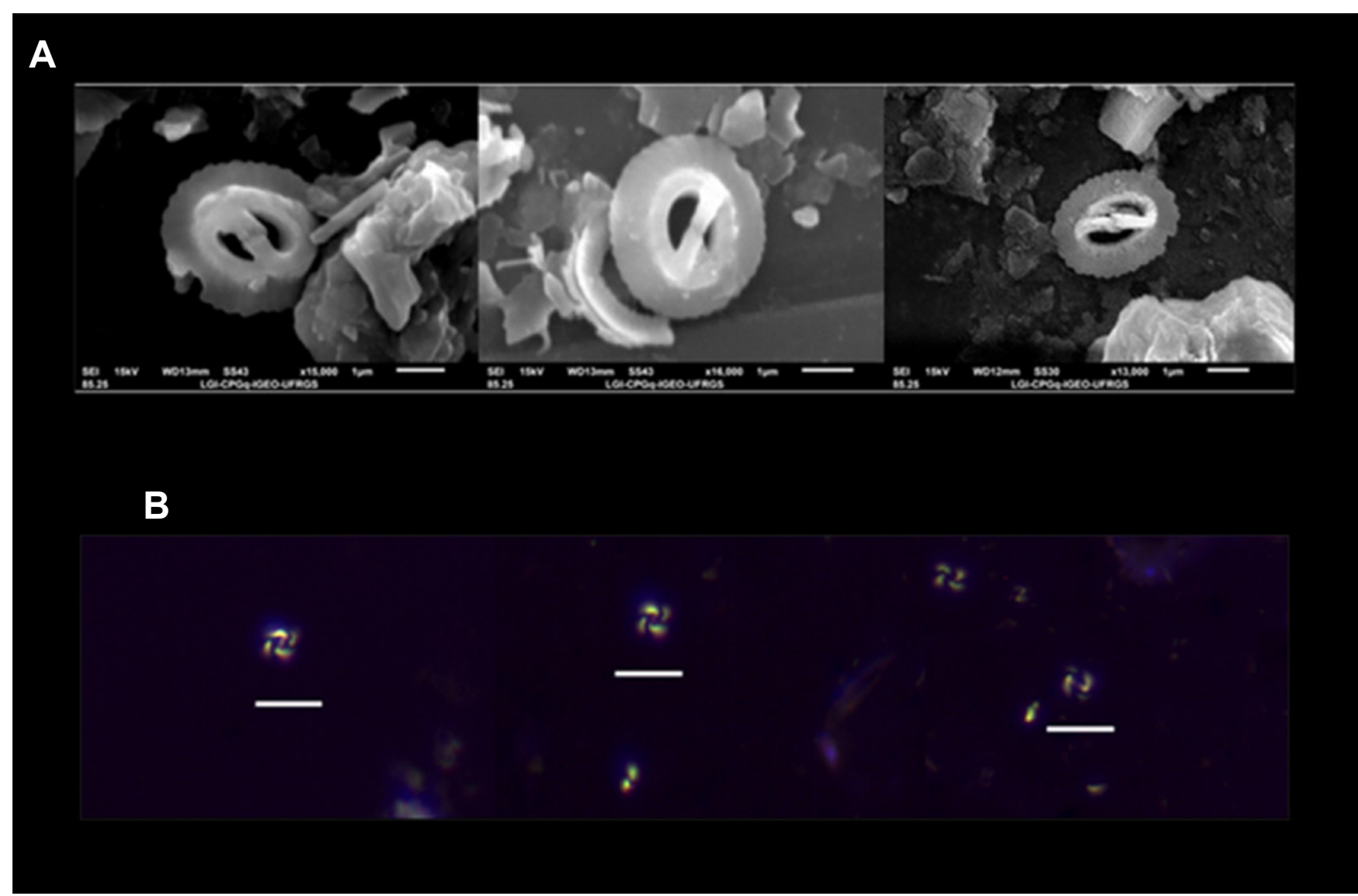

Figure 6. Images of equatorial Gephyrocapsa morphotype. A, scanning electron microscope; B, optical microscope (conventional measurement). Scale bars: $A=1 \mu \mathrm{m} ; B=5 \mu \mathrm{m}$.

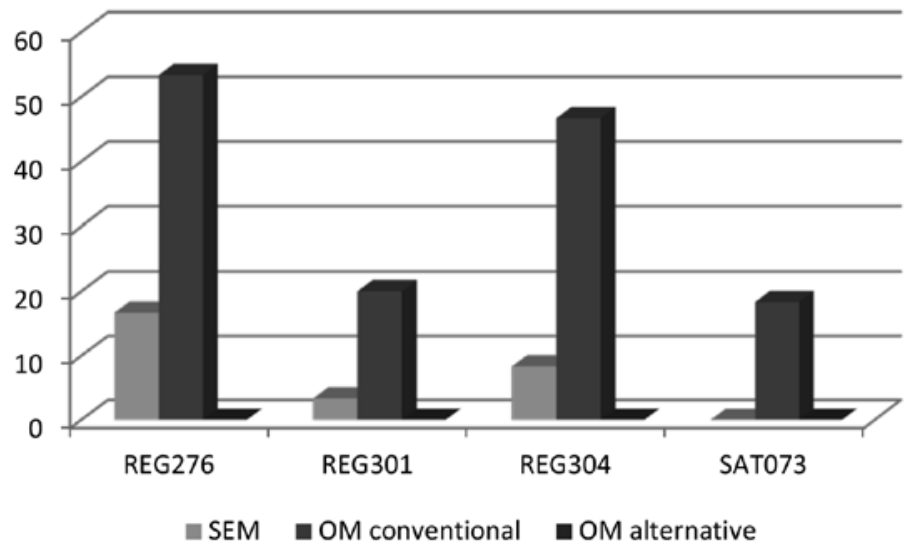

Figure 7. Percentages of equatorial Gephyrocapsa morphotype in analyzed samples with SEM and the OM.

REG301. This morphotype was not found in any sample analyses using $\mathrm{OM}_{\text {ALTERnATIVE }}$ (Figure 15).

The minute Gephyrocapsa morphotype (Figure 16) was not found in various analyzed samples. For sample SAT073, coccoliths of this morphotype were not found in either microscope. In samples REG276 and REG301, coccoliths

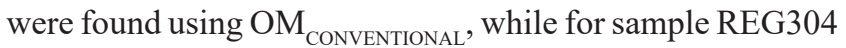
coccoliths were not found using the SEM. This morphotype was not found in any sample analyses with $\mathrm{OM}_{\text {ALTERNATIVE }}$ (Figure 17).
Furthermore, some coccoliths measured with the OM could not be classified by morphotype because they presented very high values for angle of inclination of the central bar. Samples REG 301 and REG 304 presented coccoliths that did not correspond to any morphotypes using the OM $\mathrm{M}_{\text {CONVENTIONAL }}$ method. The sample REG 304 also presented coccoliths that did not correspond to any morphotype using the $\mathrm{OM}_{\text {ALTERNATIVE }}$ method (Figure 18).

Results showed a disparity between observations with the OM and the SEM. In fact, correlations between 


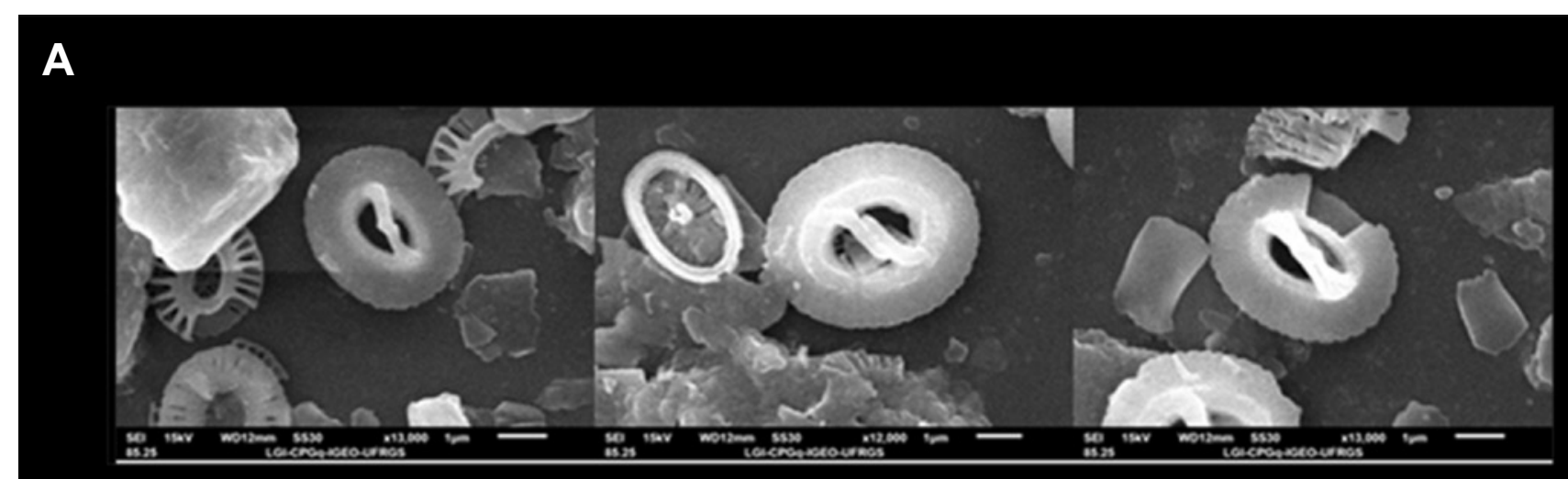

B

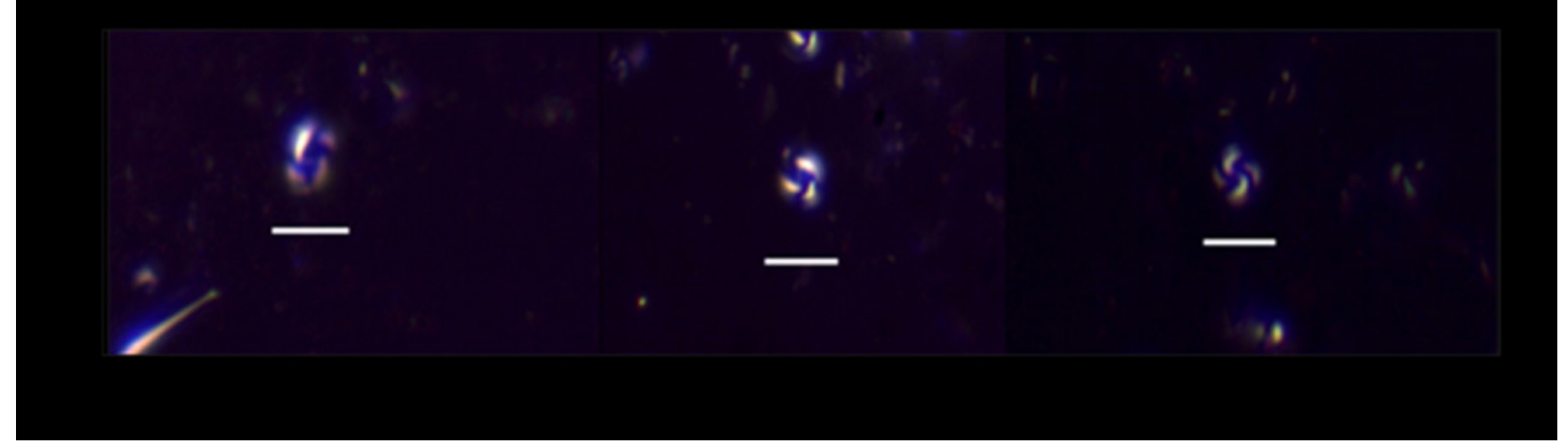

Figure 8. Images of oligotrophic Gephyrocapsa. A, scanning electron microscope; B, optical microscope (conventional measurement). Scale bars: $A=1 \mu \mathrm{m} ; B=5 \mu \mathrm{m}$.

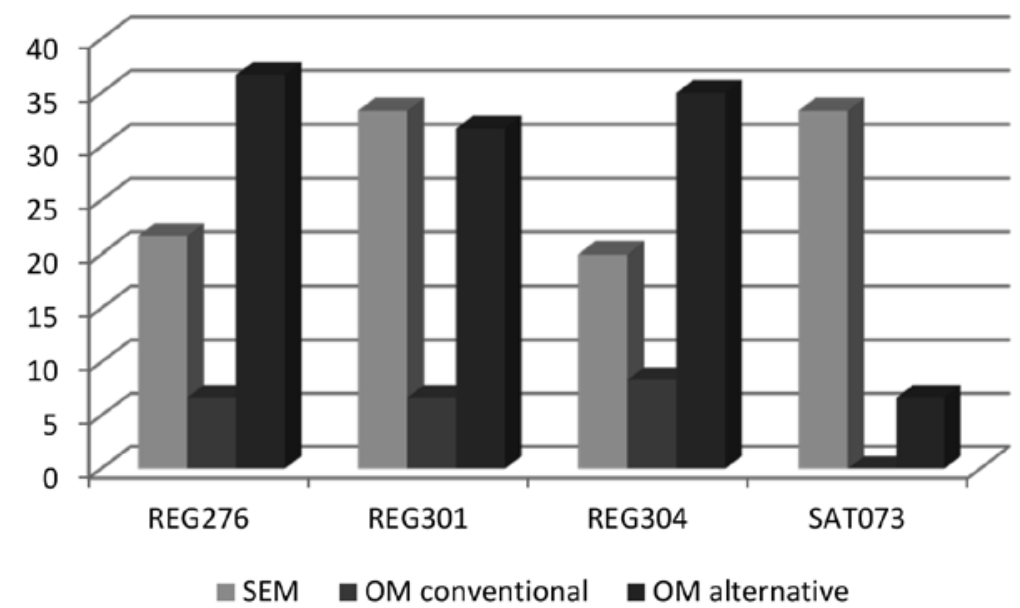

Figure 9. Percentages of oligotrophic Gephyrocapsa in analyzed samples with SEM and OM.

morphotype proportions in the analyzed samples with $\mathrm{OM}_{\text {CONVENTIONAL }}$ and the SEM were considered very low for the majority of the samples: REG276 - 0.14114; REG301 0.2207; REG304 - 0.077396. The SAT073 sample presented a strong correlation between microscopes (0.77009) (Figure 19). However, this high correlation must be related to the absence of minute and transitional morphotypes in both the OM $\mathrm{MONVNTIONAL}_{\text {and }}$ and SEM, and is not a real similarity between morphotype proportions found in the two analyses.
Morphotype percentages from the $\mathrm{OM}_{\text {ALTERNATIVE }}$ also show discrepancies from the percentages found in the SEM. Samples REG304 and SAT073 present a weak correlation between microscopes (0.36451 and 0.11564 , respectively). Samples REG276 and REG301 present strong correlations (0.81125 e 0.72921 , respectively) (Figure 20). However, in the four analyzed samples (even those that present a strong correlation with the SEM), the morphotypes minute, larger and equatorial were not identified in the $\mathrm{OM}_{\text {ALTERnATIVE }}$ (while they were present in the SEM). Therefore, the strong correlations in 


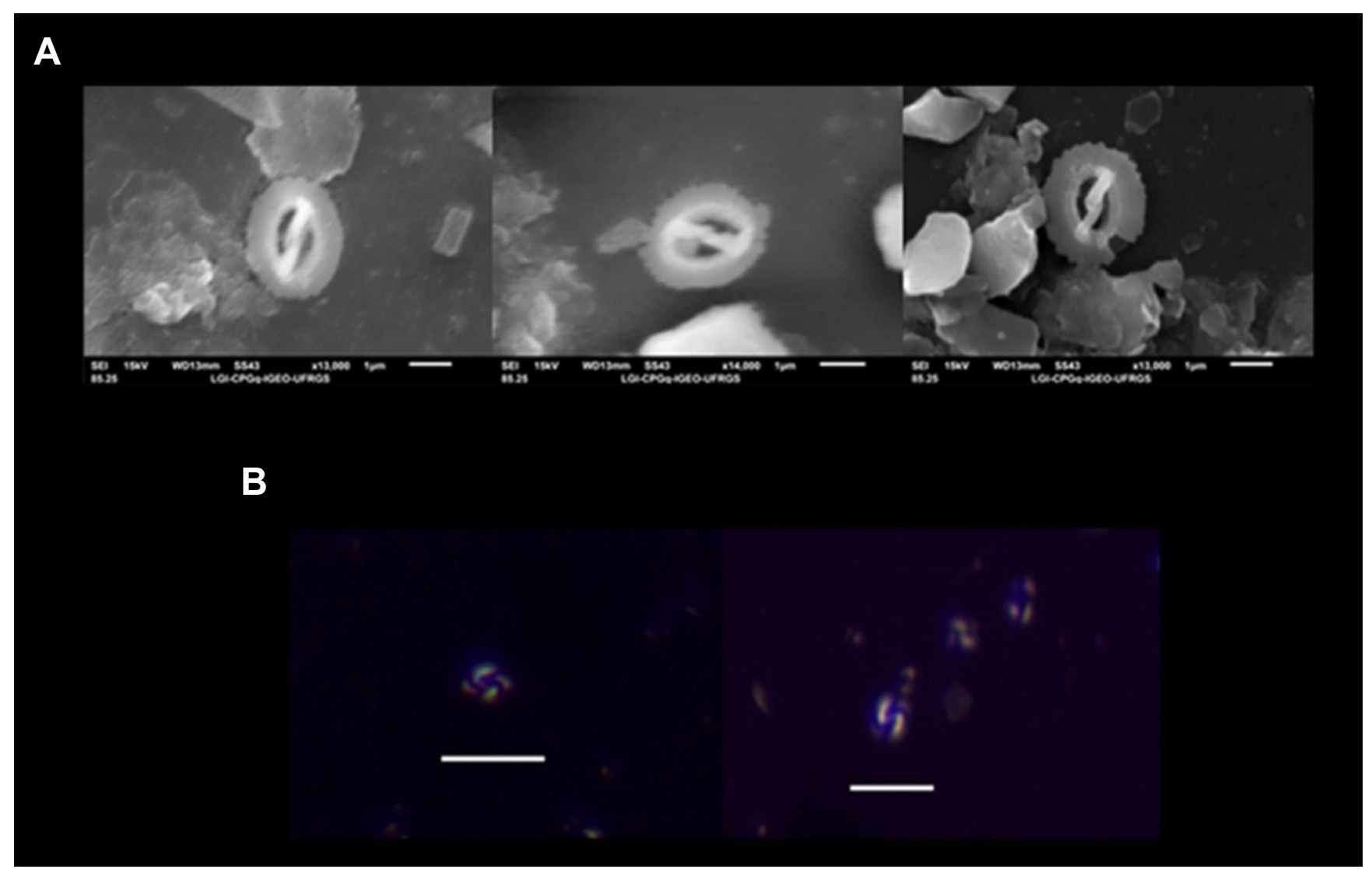

Figure 10. Images of transitional Gephyrocapsa. A, scanning electron microscope; B, optical microscope (conventional measurement). Scale bars: $A=1 \mu \mathrm{m} ; B=5 \mu \mathrm{m}$.



Figure 11. Percentages of transitional Gephyrocapsa in analyzed samples with SEM and OM.

these analyses do not seem to reflect real similarities between the results obtained in the two microscopes.

Analyzing the results obtained, it is clear that it was not possible to identify with certainty Gephyrocapsa morphotypes with the OM. The image obtained with the OM represents the sum of the interaction of the light with the polarizing filters of the petrographic microscope and the shields of the coccoliths. Characteristics that are indispensable to perfectly classifying morphotypes are affected in the OM. To define morphotypes, Bollmann (1997) measured coccoliths from their distal shield.
With the SEM, characteristics of the distal shield coccolith's and the proximal shield are very distinct. With the OM, it is not possible to differentiate the distal shield from the proximal shield. In many genera of the Noelaerhabdaceae family, both the distal and proximal shields produce birefringence when observed with crossed polarizers in a petrographic OM; therefore, coccoliths seem bigger than their actual size (Saéz 1998), which complicates the measurement of their greatest length. It is therefore likely that the coccolith's greatest length is frequently positioned incorrectly in the OM, which would 


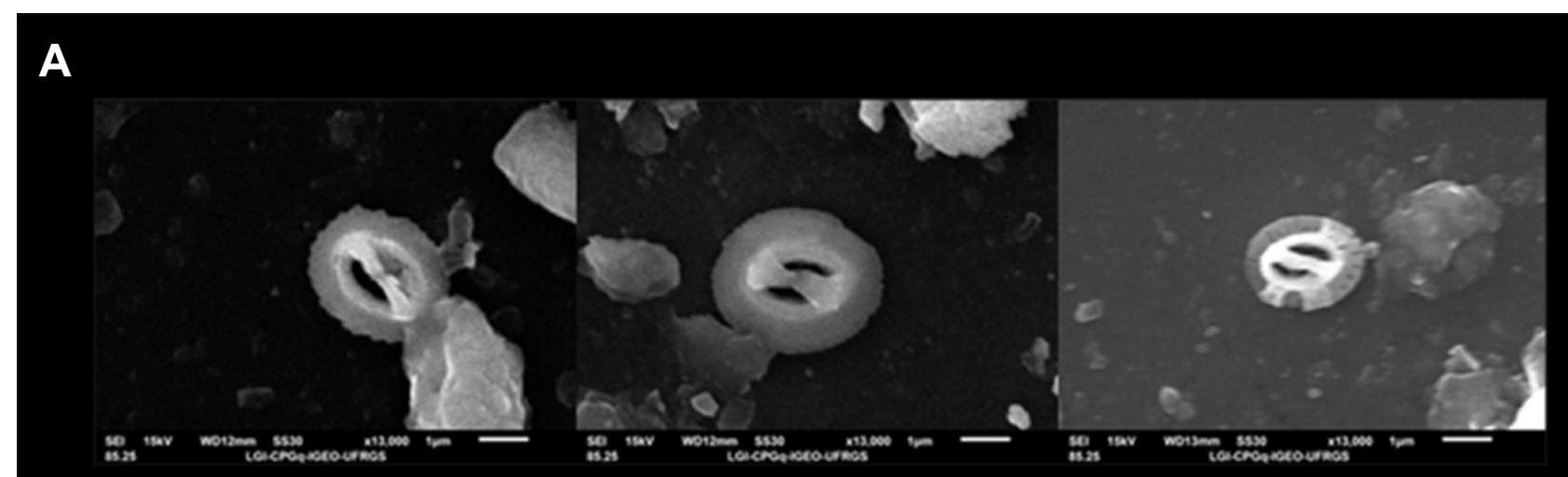

B

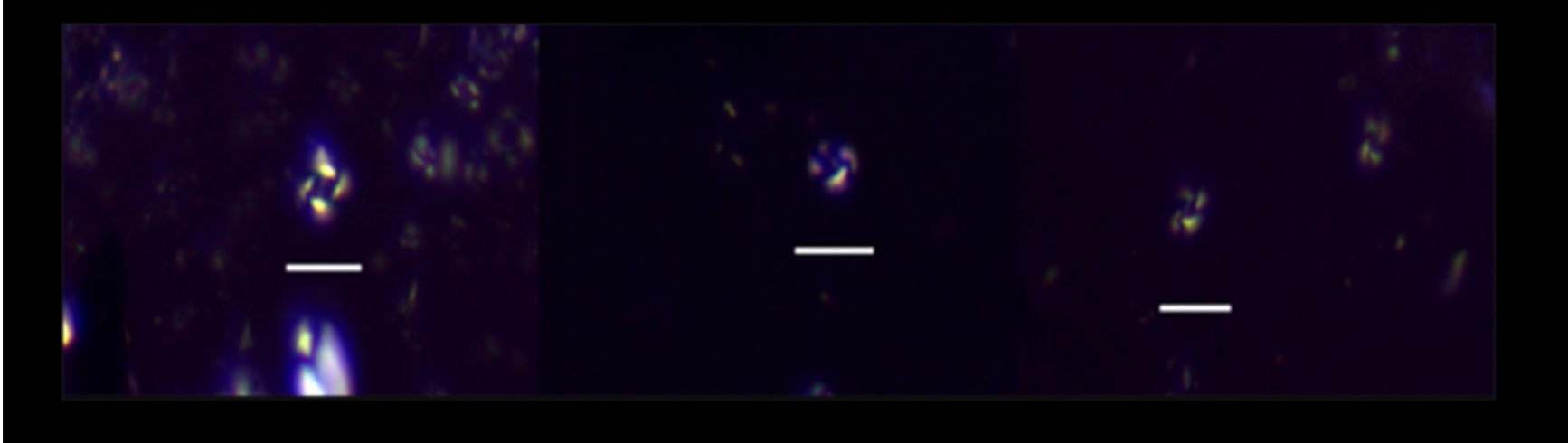

Figure 12. Images of cold Gephyrocapsa morphotype. A, scanning electron microscope; B, optical microscope (conventional measurement). Scale bars: $A=1 \mu \mathrm{m} ; B=5 \mu \mathrm{m}$.



Figure 13. Percentages of cold Gephyrocapsa in analyzed samples with SEM and OM.

also affect the measurement of the angle of inclination of the central bar. For these reasons, many coccoliths are classified differently in the OM than if they were observed in the SEM. In some cases, it was not possible to classify coccolith morphotypes with the OM $\mathrm{M}_{\text {CONVENTIONAL }}$. However, many of them were simply not recognized with the $\mathrm{OM}_{\text {ALTERNATIVE }}$ (while they were present in the SEM analysis). Therefore, comparing the obtained results, the strategy that best measured and represented the morphotypes defined by Bollmann (1997) was the $\mathrm{OM}_{\text {CONVENTIONAL. }}$

\section{Calculation of SST}

Paleotemperatures were calculated (Table 3) using the equation proposed by Bollmann et al. (2002) from the proportion of Gephyrocapsa morphotypes in each sample. As most morphotypes are easily identified in the SEM, the SST 


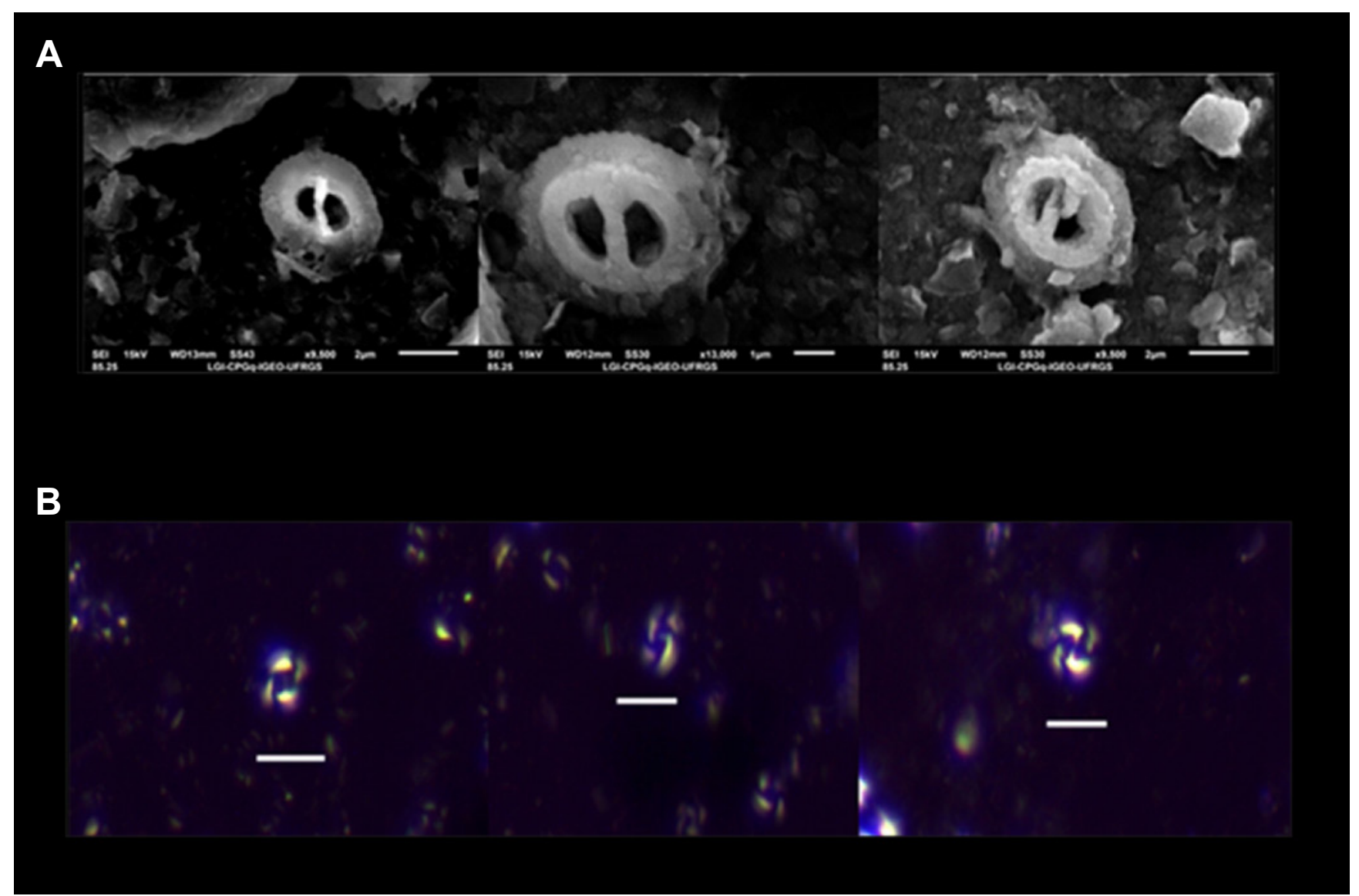

Figure 14. Images of larger Gephyrocapsa. A, Scanning Electron Microscope (scale: $2 \mu \mathrm{m}, 1 \mu \mathrm{m}$, and $2 \mu \mathrm{m}$, respectively); B, Optical Microscope (conventional measurement) (scale: $5 \mu \mathrm{m}$ ).



Figure 15. Percentages of larger Gephyrocapsa in analyzed samples with SEM and OM.

obtained from observations in this microscope was considered real. In almost all cases, the SST was underestimated in the $\mathrm{OM}_{\text {CONVENTIONAL }}$. Sample SAT073 was an exception, because the paleotemperatures estimated from the $\mathrm{OM}_{\text {CONVENTIONAL }}$ and the SEM were very similar. The difference in SST values in the microscopes varied from -5.28 to $0.18^{\circ} \mathrm{C}$.

The SSTs found from the morphotypes observed in the $\mathrm{OM}_{\text {ALTERnATIVE }}$ are very different from those found with the $\mathrm{OM}_{\text {CONVENTIONAL }}$, presenting underestimated values in comparison to the morphotypes observed with the SEM. The difference between the SST values obtained in the microscopes varied from 0.51 to $6.82^{\circ} \mathrm{C}$.

When we compare the calculated paleotemperature values from the OM and the SEM, there are discrepancies in the values obtained, which was expected based on the results already presented. This indicates that the estimates obtained 


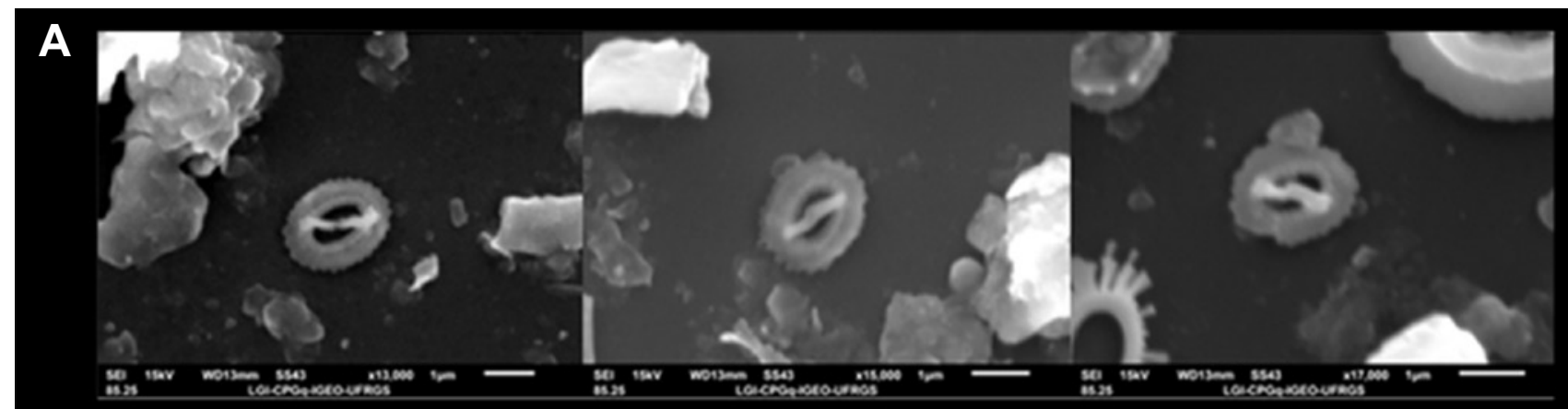

B

Figure 16. Images of minute Gephyrocapsa. A, scanning electron microscope; B, optical microscope (conventional measurement). Scale bars: $A=1 \mu \mathrm{m} ; B=5 \mu \mathrm{m}$.

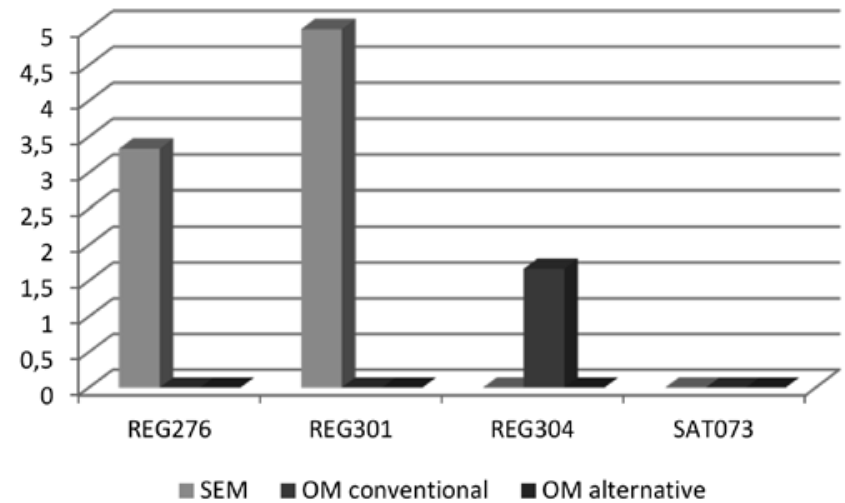

Figure 17. Percentages of minute Gephyrocapsa in analyzed samples with SEM and OM.

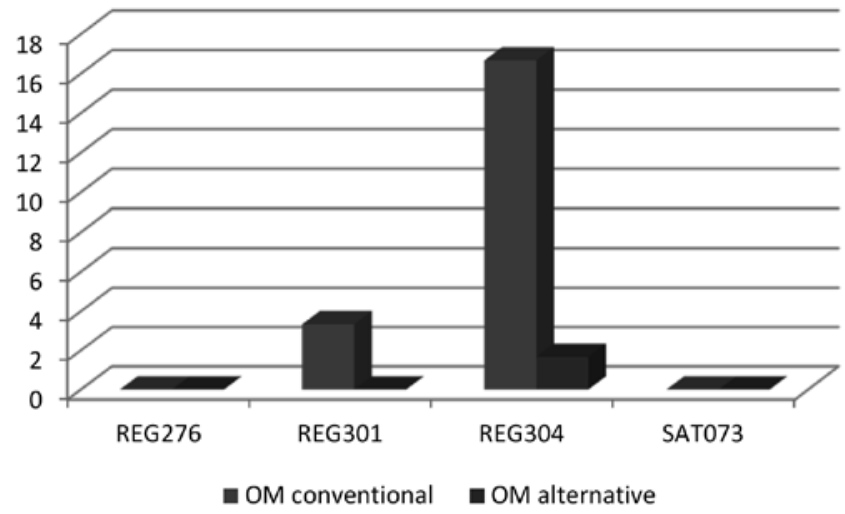

Figure 18. Percentages of Gephyrocapsa coccoliths that do not correspond to any morphotypes of all samples analyzed using OM. 

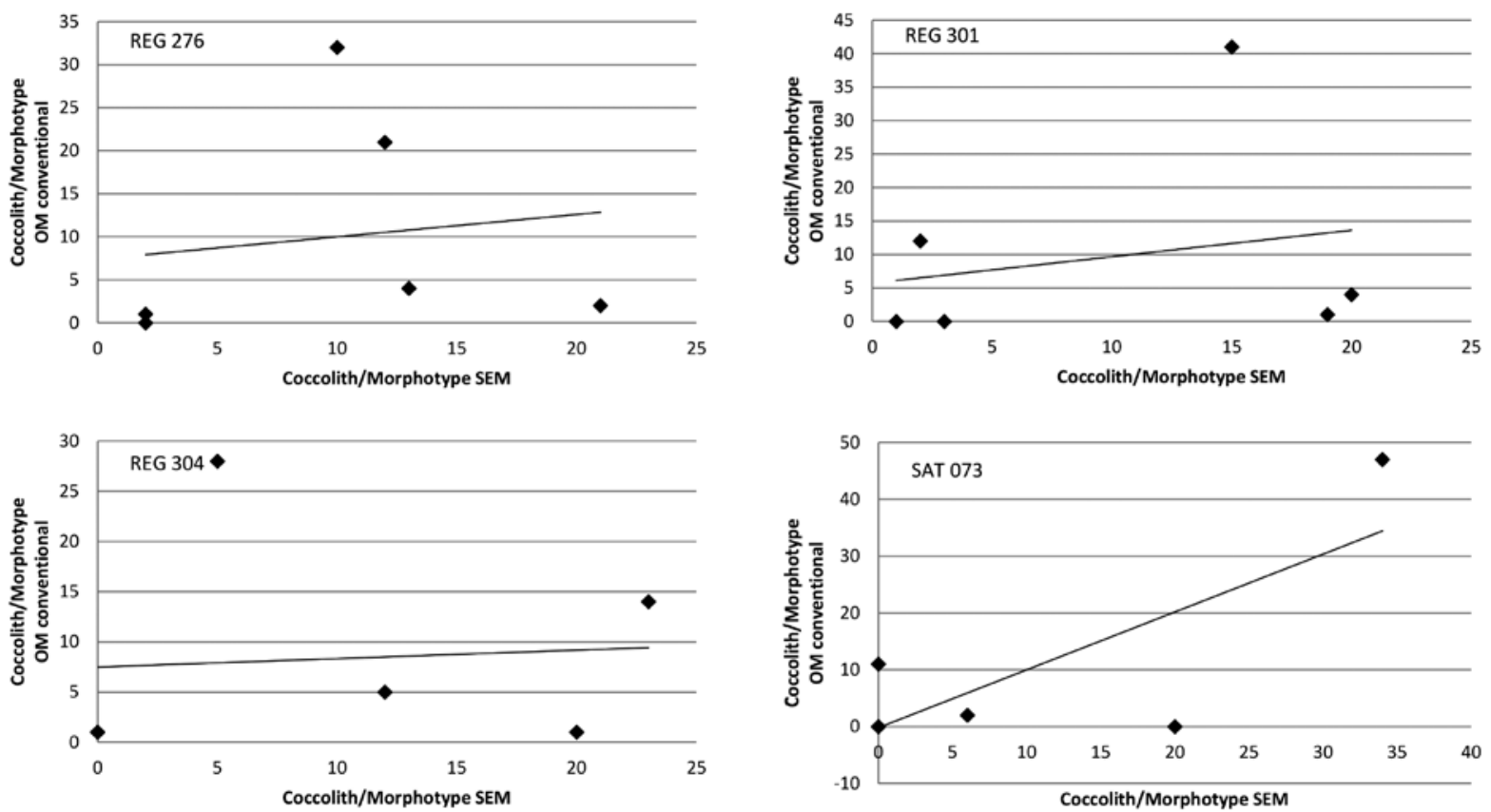

Figure 19. Ratio of number of coccoliths found per morphotype with $\mathrm{OM}_{\text {CONVENTINAL }}$ and SEM, in each sample.
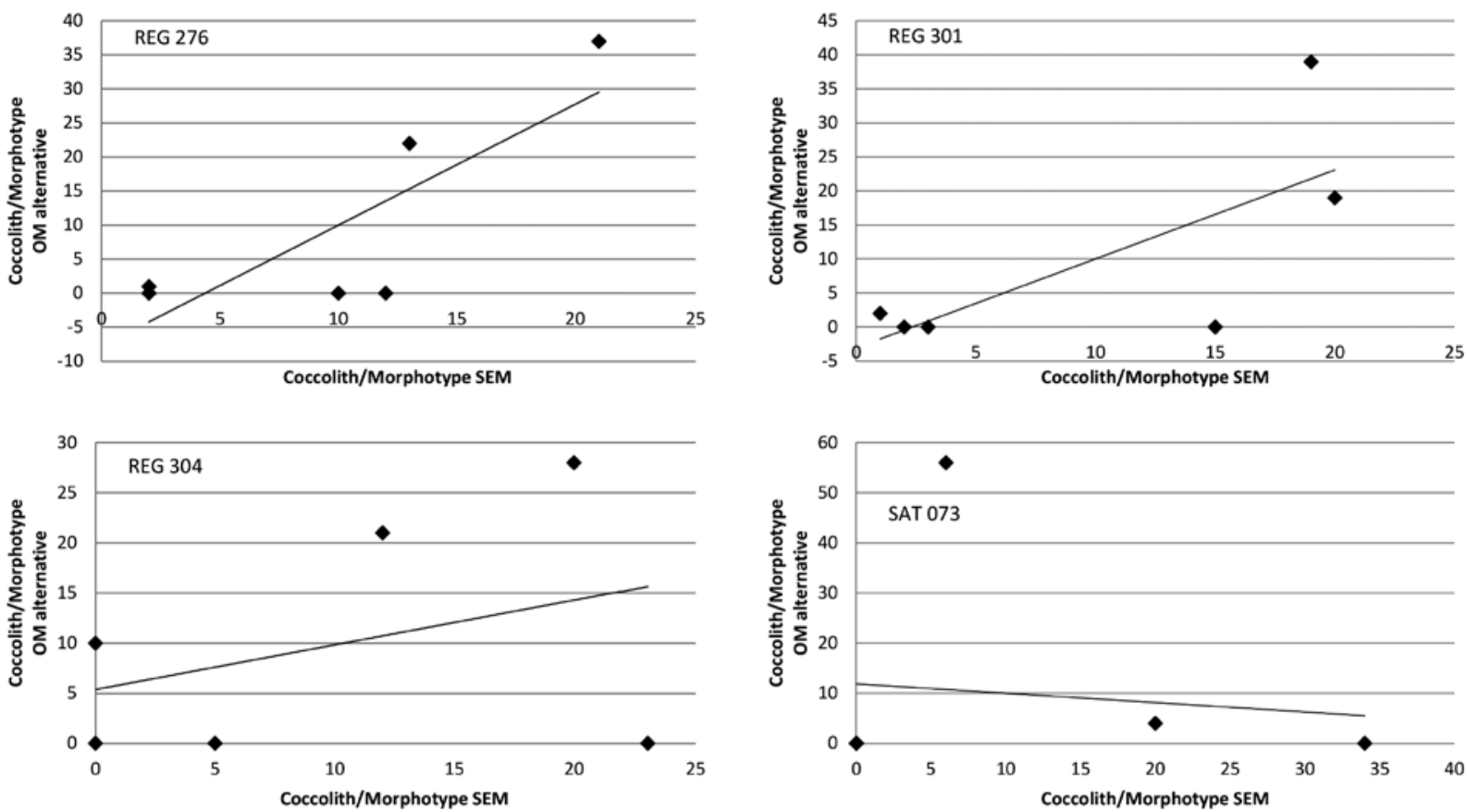

Figure 20. Ratio of number of coccoliths found per morphotype with $\mathrm{OM}_{\text {ALTERNATIVE }}$ and SEM, for each sample.

Table 3. Calculated values of SST based on proportion of Gephyrocapsa morphotypes in samples analyzed with the OM and the SEM.

\begin{tabular}{lcccc}
\hline & REG276 & REG301 & REG304 & SAT073 \\
\hline SST $\left({ }^{\circ} \mathrm{C}\right)$ : samples analyzed in the SEM & 20.90 & 20.73 & 20.15 & 21.56 \\
$\mathrm{SST}\left({ }^{\circ} \mathrm{C}\right)$ : samples analyzed with $\mathrm{OM}_{\text {CONVENTIONAL }}$ & 25.98 & 22.20 & 25.43 & 21.38 \\
$\mathrm{SST}_{\text {SEM }}-\mathrm{SST}_{\text {OM CONVENTIONAL }}$ & -5.08 & -1.47 & -5.28 & 0.18 \\
$\left.\mathrm{SST}^{\circ} \mathrm{C}\right)$ : ${\text { Samples analyzed with } \mathrm{OM}_{\text {ALTERNATIVE }}}_{\mathrm{SST}_{\text {SEM }}-\mathrm{SST}_{\text {OM ALTERNATIVE }}}^{18.94}$ & 18.35 & 19.64 & 14.74 \\
\hline
\end{tabular}


using the $\mathrm{OM}$ are not reliable. The disparity between obtained SST also varied considerably, from $1^{\circ} \mathrm{C}$ to almost $6^{\circ} \mathrm{C}$. If the encountered error were constant, the SSTs obtained could still be used to understand paleotemperataure trends over time, but this does not appear possible.

\section{CONCLUSIONS}

According to the data collected and analyzed in the study, we can conclude that (i) all Gephyrocapsa morphotypes were found in the SEM analysis and are therefore represented in the study area; (ii) it was not possible to correctly identify Gephyrocapsa morphotypes in the OM analysis, because the type of image that was obtained complicates measurements, especially the central bar's angle of inclination. The image obtained with the $\mathrm{OM}$ represents the sum of the interaction of the light with the polarizing filters of the petrographic microscope and the shields of the coccoliths. This affects the recognition of indispensable characteristics in the classification of morphotypes and (iii) the calculated SST from proportions of observed morphotypes with the OM are unrealistic and should not be used to assess trends in paleotemperature.

\section{ACKNOWLEDGMENTS}

The authors would like to thank FAPERGS (Fundação de Amparo à Pesquisa do Estado do Rio Grande do Sul) for financing the analyses (process number 167612-3). T.S would also like to thank CAPES (Coordenação de Aperfeiçoamento de Pessoal de Nível Superior) for the academic scholarship, which made this study possible.

\section{REFERENCES}

Bollmann, J. 1997. Morphology and biogeography of Gephyrocapsa coccoliths in Holocene sediments. Marine Micropaleontology, 29:319-350. doi:10.1016/S0377-8398(96)00028-X

Bollmann, J.; Henderiks, J. \& Brabec, B. 2002. Global calibration of Gephyrocapsa coccolith abundance in Holocene sediments for paleotemperature assessment. Paleoceanography, 17:7.1-7.9. doi:10.1029/2001PA000742

Bollmann, J. \& Herrle, J.O. 2007. Morphological variation of Emiliania huxleyi and sea surface salinity. Earth and Planetary Science Letters, 255:273-288. doi:10.1016/j.epsl.2006.12.029
Hagino, K.; Okada, H. \& Matsuoka, H. 2005. Coccolithophores assemblages and morphotypes of Emiliania huxleyi in the boundary zone between the cold Oyashio and warm Kuroshio currents off the coast of Japan. Marine Micropaleontology. 55:19-47. doi:10.1016/j.marmicro.2005.02.002

Koch, C. \& Young, J.R. 2007. A simple weighing and dilution technique for determining absolute abundances of coccoliths from sediment samples. Journal of Nannoplankton Research, 29:67-69.

Matsuoka, H. \& Okada, H. 1990. Time-progressive morphometric changes of the genus Gephyrocapsa in the Quaternary sequence of the tropical Indian Ocean, site 709. In: R.A. Duncan; J. Backman \& L.C. Peterson (eds) Proceedings of the Ocean Drilling Program, College Station, Ocean Drilling Program, p. 255-270. (Scientific Results115). doi:10.2973/odp.proc. sr. 115.155 .1990

Perch-Nielsen, K. 1985.Cenozoic calcareous nannofossils. In: H.M. Bolli; J.B. Saunders \& K. Perch-Nielsen (eds) Plankton stratigraphy, Cambridge University Press, p. 329-426.

Pillar, V.D. 2006. MULTIV: Multivariate Exploratory Analysis, Randomization Testing and Bootstrap Resampling, User's Guide v. 2.1. Universidade Federal do Rio Grande do Sul, Porto Alegre. Available at http://ecoqua.ecologia.ufrgs.br/arquivos/Software/ Multiv/MultivManual.pdf; accessed on 15/12/2016.

Renaud, S.; Ziveri, P. \& Broerse, A.T.C. 2002. Geographical and seasonal differences in morphology and dynamics of the coccolithophore Calcidiscus leptoporus. Marine Micropaleontology, 46:363-385. doi:10.1016/S03778398(02)00081-6

Rio, D. 1982. The fossil distribution of coccolithophore genus Gephyrocapsa Kamptner and related Plio-Pleistocene chronostratigraphic problems. In: W.L. Prell \& J.V. Gardner (eds) Initial Reports of the Deep Sea Drilling Project, Washington, U.S. Government Printing Office, p. 325-343 (Volume 68). doi:10.2973/dsdp.proc.68.109.1982

Roth, P.H. 1994. Distribution of coccoliths in oceanic sediments. In: A. Winter \& W.G. Siesser (eds) Coccolithophores, Cambridge University Press, p. 199-218.

Young, J.R.; Bergen, J.A.; Bown, P.R.; Burnett, J.A.; Fiorentino, A.; Jordan, R.W.; Kleijene, A.; Van Niel, B.E.; Ton Romein, A.J. \& Salis, K.V. 1997. Guidelines for coccolith and calcareous nannofossil terminology. Paleontology, 40:875-912.

Young, J.R.; Henriksen, K. \& Probert, I. 2004. Structure and morphogenesis of the coccoliths of the CODENET species. In: H.R. Thierstein \& J.R. Young (eds) Coccolithophores: from molecular processes to global impact, Springer, p.191-215.

Received in June, 2016; accepted in September, 2016. 